\title{
Environment and Social Impacts of Stone Quarrying: South Western Ethiopia, in Case of Bahir Dar Zuria Wereda Zenzelma Kebele
}

\author{
Awoke Endalew (BSc) ${ }^{1 *}$, Endalew tasew $(\mathrm{BSc})^{2}$, Solomon tolahun $(\mathrm{BSc})^{3}$ \\ Bahir Dar, Ethiopia
}

*Corresponding Author: Awoke Endalew, Bahir Dar, Ethiopia

\begin{abstract}
The study aims to assess the environmental and social impacts of stone quarry in Zenzelima Kebele. It has employed a descriptive survey design. The study area was purposively selected based on the concentration and environmental pressure of quarry activity. 60 household heads were selected using simple random sampling technique. In addition, seven key informants were selected by purposive sampling technique. The data were collected using survey questionnaire, key informant interview and field observation. It were analyzed by using descriptive statistics such as frequency distributions and percentages. The study findings indicated that the major socio-environmental impacts of stone quarrying are reduction of agricultural yields, farm obstacle, loss of biodiversity, habitat and deforestation, land use change,change landscape,block free movement of animals, erosion and sedimentation, loss of aestatic value, death of livestock, death of human, property damage, air pollution (dust) and health related impacts such as stress, and coughs and colds. The local residents and cobble stone worker had not have any awareness about the impact of stone quarrying on the environment and society and did not get any training from the Government Administration, NGOs or anybody else about the proper extraction and management of stone quarrying.
\end{abstract}

Keywords: Quarry; Biodiversity; Pollution; Cobble; Impact

\section{INTRODUCTION}

\subsection{Background and Justification}

All over the world there is a realization that quarrying activities has evolved over time to mining industry that has the potential to provide hither to unparalleled services to management in their efforts to reduce effects of quarrying risks to the human being and the surroundings. This potentially has been turned into a challenge and embodied in the new definition of quarrying from the committee of sponsoring organization of the tread way commission on quarrying activities. Quarries are generally used for extracting construction materials, such as dimension stone, ornamental stones and road, building and industrial raw materials. A quarry is a type of open-pit surface mining from which rock or minerals are extracted. However, mining and quarrying are destructive enterprises (Sinha, et al., 2000) and involve the complete destruction of the habitat of an area where they take place (MartínezRuiz et.al, 2007). The destruction and fragmentation of habitat is the greatest threat to biodiversity and the primary cause of species extinction (Aronson et al., 1993).

In most Africans nations and others nations, quarrying is not well managed for environmental sustainability (Darwish et al, 2010). The methods used are very poor and there is no order in resource exploitation. Most of the quarries do collapse and there is no measures taken to rehabilitation to such quarries since most of them are left open. Therefore, the need for detailed study on the significance of quarrying management on mining industries has become inevitable. Since the effects of quarrying cover all tenants of effective strategic management, ethical corporate governance and ensures quarrying are managed in an integrated and structured manner that boosts institutions in quarrying perform (Nyakeniga, 2009). One of the biggest negative impacts of quarrying on the environment is the damage to biodiversity (Anand, 2006). Quarrying carries the potential of destroying habitats and the species they support (Mabogunje, 2008). Even if the habitats are not directly removed by excavation, they can be indirectly affected and damaged by environmental impacts such as changes to ground water or surface water that causes some habitats to dry out or others to become flooded. Even noise pollution can have a significant impact on some species and affect their successful reproduction. 
Nevertheless, with careful planning and management, it is possible to minimize the effect on biodiversity and in fact, quarries can also provide a good opportunity to create new habitats or to restore existing ones (Tanko, 2007).Again, like many other man-made activities, quarrying, involves the production of significant amounts of waste. Some types of quarries do not produce large amounts of permanent waste, such as sand and gravel quarries, whereas others will produce significant amounts of waste material such as clay and silt (Wang, 2007).

While quarries can cause significant impact to the environment, with the right planning and management, many of the negative effects can be minimized or controlled and in many cases, there is great opportunity to protect and enhance the environment, such as with the translocation of existing habitats or the creation of new ones. Therefore to achieve the equilibrium between natural ecosystems, project planning, formulation and implementation is needed to avoid the impact of stone quarry on the environment and living community. In this study, the we will be assess the environmental and the social impact of quarry activity at Zenzelma kebele.

Following the rapid urban expansion of Bahir Dar city, extensive infrastructure and housing development projects are under way and a significant boom in construction material supply, most of which is mainly extracted from the peri-urban areas of the city. There are many quarrying projects undertaken in the peri-urban areas found around Bahir Dar city. In those areas there have been quarries used to produce concret that contribute to the various types of construction and provide both economic and social benefits.

However, the intensive activities of quarrying disregard to the environment impact leads to a series of socio-economic and environmental problems. Hence, the study area is one of the most potential quarry sites that create large job opportunity and, supply different construction materials mainly concret for building construction, it is observed that various environmental problems, such as the excavated site is abandoned and left as wasteland, the overburden materials are improperly dumped for future rehabilitation, soil is eroded and land is degraded, natural river water flow is diverted and impact on groundwater recharge. Besides, the quarry sites in the study area have great problem on the management practice which can be characterized by poor mining plan, lack of ecological considerations, inadequate quarrying process and rehabilitation planning, technical and policy enforcement barriers, which aggravate significantly the degradation on the environment and social development endeavors in the city, so it needs conducting research on the site to identify the degree of impacts and to take remedy measures. It is difficult to take a sustainable mitigation measure without detail investigation of the impacts. Therefore, this study seeks to investigate the impacts of stone quarrying on the physical as well as social environment at the study area.

\section{MeThOdOLOGY}

\subsection{Description of the Study Area}

Zenzelma (study area) is one of the kebele in Bahirdar zuria woreda, west Gojjam zone of Amhara region; Ethiopia. It is geographically located between 11 o $35^{\prime} \mathrm{N}$ and 11040 ' $\mathrm{N}$ latitude and $37 \mathrm{o} 24^{\prime} \mathrm{E}$ and 37o 29' longitude with an altitudinal range 1917 above mean sea leve. The area has 3707.61 ha (zenzelm kebele agricultural office; 2017)

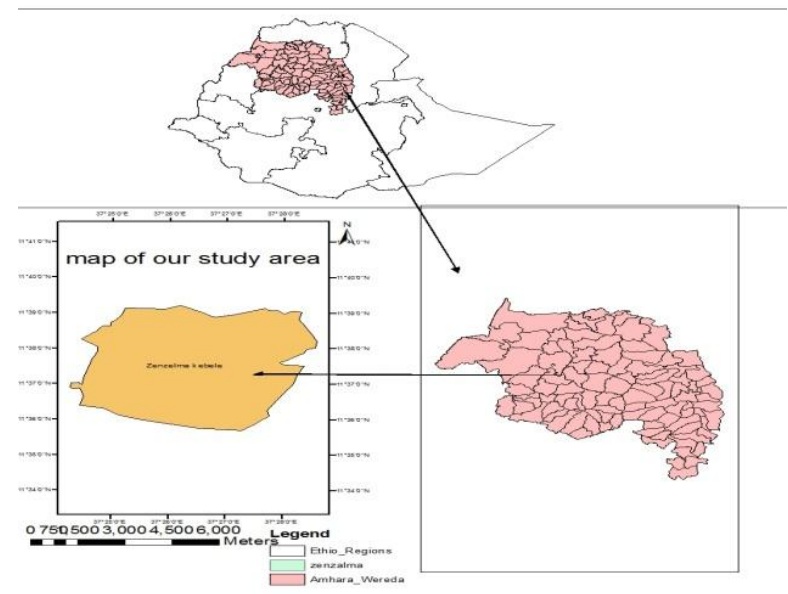




\subsection{Research Design}

The study was aimed to assess the impact of stone quarry on the environment and the societies in the case of Bahir Dar district Zenzelma kebele. To obtain appropriate information, a descriptive survey research design was used because it is suitable for describing the existing situation, narrating facts and investigating phenomena.

\subsection{Types and Sources of Data}

Both primary and secondary data sources were used for this study in order to achieve the objectives. The primary data was obtained from systematically selected households, local government administration, construction workers and non-governmental organizations and professionals workings on stone constructions using surveys, questionnaires, interviews, focus group discussions and personal observation. Relevant secondary data was obtained from published and unpublished office documents, government and non-governmental organizations, articles, journals, reports and books.

\subsection{Sampling Techniques and Sample}

A multistage sampling technique was used for the study. Where, first step; Zenzelima kebele is selected purposively to address the impact of stone quarrying on environment and the surrounding society; because the environment and society is significantly affected by stone quarrying, and the study area is proximal to the campus (it is difficult to conduct in other far places we don't known before).Then the second step; samples from these three sub kebele namely: Michealnius, Sesabert and Gedro were selected by using simple random sampling using slovin`s sampling formula to determine sample respondents.

Slovin Formula: $\mathrm{n}=\mathrm{N}$

$$
1+\mathrm{N}(\mathrm{E})^{2}
$$

Where: $\mathrm{n}=$ sample size

$\mathrm{N}=$ total number of household from three sub-kebeles

$\mathrm{E}=$ margin of error

$\mathrm{N}=1782$ house holds

$\mathrm{E}=0.05$

The above formula shows that the actual sample size for this study is 315 , but due to time and financial constraint, we reduce the sample size into 60 respondents. Proportional sample size based on the household is essential to determine the number of respondent from three sub kebeles.

\subsection{Method of Data Analysis}

In order to answer the research questions of the study, we were utilized both quantitative and qualitative research approaches. A quantitative method was used to quantify numerical data relating to the study, which was obtained from closed ended questions. Qualitative methods were used to explore information from key informant interview and direct observation towards the impact of stone quarrying on the environment and the societies. Data generated by closed ended questions were analyzed and interpreted quantitatively using simple descriptive statistics, such as percentage and frequency supported by concise discussions. Descriptive tools such as bar graphs, tables and pie charts were employed to present results.

\section{RESULTS AND DISCUSSION}

The study were seek to investigate the impact of stone quarrying on the environment and societies. In this case, responses were sought from questionnaire, key informant interview and observation.

\subsection{Social and Environmental Impact of Stone Quarrying}

Quarrying activity often have long-term social, and environmental impacts. Social challenges related to the increase in quarrying activities in general include: threats to health and safety, farming obstacle, block free movement of animals, displacement of communities, reduction in agricultural yield, damage of cultural sites, and the formation of mining villages. One of the major problem is that, while the mining companies (and to a lesser extent, the government) pick the biggest share of the benefits from quarrying; while local communities suffer from the negative impacts of these projects. In Zenzelma kebele the respondent's response about the impact of stone quarrying on the environment and society in the following manner. 
Environment and Social Impacts of Stone Quarrying: South Western Ethiopia, in Case of Bahir Dar Zuria Wereda Zenzelma Kebele

Table1. Socio-environmental impacts responded by respondents

\begin{tabular}{|c|c|c|c|c|c|c|c|}
\hline \multirow[t]{2}{*}{ No } & \multirow[t]{2}{*}{ Impacts } & \multicolumn{2}{|l|}{ Yes } & \multicolumn{2}{|l|}{$\mathrm{No}$} & \multicolumn{2}{|l|}{ Total } \\
\hline & & Frequency & $\begin{array}{l}\text { Percentage } \\
(\%)\end{array}$ & Frequency & $\begin{array}{l}\text { Percentage } \\
(\%)\end{array}$ & Frequency & Percentage $(\%)$ \\
\hline 1 & $\begin{array}{l}\text { Reduction in } \\
\text { crop production } \\
\text { yield }\end{array}$ & 42 & 70 & 18 & 30 & 60 & 100 \\
\hline 2 & Farm obstacle & 49 & 81.7 & 11 & 18.3 & 60 & 100 \\
\hline 3 & $\begin{array}{l}\text { Loss of } \\
\text { biodiversity, } \\
\text { habitat and } \\
\text { deforestation }\end{array}$ & 38 & 63.3 & 22 & 36.7 & 60 & 100 \\
\hline 4 & $\begin{array}{ll}\text { Land } & \text { use } \\
\text { change } & \end{array}$ & 37 & 61.7 & 23 & 38.3 & 60 & 100 \\
\hline 5 & $\begin{array}{l}\text { Change } \\
\text { landscape }\end{array}$ & 45 & 75 & 15 & 25 & 60 & 100 \\
\hline 6 & $\begin{array}{lr}\text { Block } & \text { free } \\
\text { movement } & \text { of } \\
\text { animals } & \\
\end{array}$ & 39 & 65 & 21 & 35 & 60 & 100 \\
\hline 7 & $\begin{array}{l}\text { Erosion and } \\
\text { sedimentation }\end{array}$ & 41 & 68.3 & 19 & 31.7 & 60 & 100 \\
\hline 8 & $\begin{array}{l}\text { Dereliction of } \\
\text { the mined site }\end{array}$ & 40 & 66.7 & 20 & 33.3 & 60 & 100 \\
\hline 9 & $\begin{array}{l}\text { Loss of aestatic } \\
\text { value }\end{array}$ & 31 & 51.7 & 29 & 48.3 & 60 & 100 \\
\hline 10 & $\begin{array}{l}\text { Death of } \\
\text { livestock }\end{array}$ & 20 & 33.3 & 40 & 66.7 & 60 & 100 \\
\hline 11 & Death of human & 31 & 51.7 & 29 & 48.3 & 60 & 100 \\
\hline 12 & $\begin{array}{l}\text { Property } \\
\text { damage }\end{array}$ & 25 & 41.7 & 35 & 58.3 & 60 & 100 \\
\hline 13 & $\begin{array}{l}\text { Air pollution } \\
\text { (dust) }\end{array}$ & 30 & 50 & 30 & 50 & 60 & 100 \\
\hline
\end{tabular}

Source. field survey, 2017

\subsubsection{Reduction of Agricultural Yields}

Accordingly to the table above, $42(70 \%)$ of the respondents were indicated that there is highly impact of stone quarry on agricultural yields reduction especially in areas where stone quarry is more concentrated. Similarly, information from key informant interview of agricultural office of Zenzelma kebele showed that quarry have high impact on agricultural yields through a number of ways. Like: reduction of arable lands, reduction of soil fertility and air pollution generally and especially dust from quarry sites are known to be responsible for vegetation injury and crop yield reduction and thus become a threat to the survival of crops in quarrying areas.

In support of the present study result, Lqbal and Shafig,(2001) stated that air pollution generally and especially dust from quarry sites are known to be responsible for vegetation injury and crop yield reduction and thus become a threat to the survival of plants in quarrying areas.

In line with the above findings, Samant (2014) revealed that the negative effect of stone quarrying was dust pollution. Dust pollution reduced agricultural yields due to dust deposition on crops and also it reduced the availability of water and ground water.

\subsubsection{Farm Obstacle}

Accordingly to the table above show that, the majority $49(81.67 \%)$ of the respondents were indicated that stone quarry is an obstacle for their farming activity. According to the local elder key informant interview and direct observation, stone quarrying have great

obstacle for agricultural activity ( it makes the agricultural land to become sloppy, abandoned hole, waste stone fill ) and it is difficult for the farmer to plough the land and to harvest crop yield. 


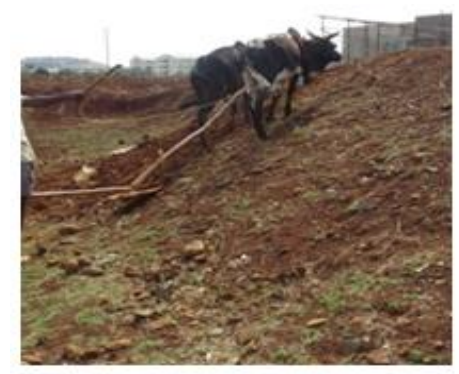

Figure 1. farming obstacle of stone quarrying

Source. field survey, 2017

\subsubsection{Loss of Biodiversity, Habitat and Deforestation}

The above table illustrates that majority 38 (63.3\%) of the respondents reported that the stone quarry have great impact on biodiversity, habitat and contributed to deforestation. According to the local elder key informant interview and direct observation in the quarry site with extreme extraction and excavation of quarrying some animals and plants species living in the study site were threatened. Some of the threatened plant species known by their vernacular/local names such as warka, ebis, eshe and animal species known by their vernacular/local names such as dkula, sesa and bezer, because of a place where animals lives and forests are loss and disturbed for the seek of quarry activity.

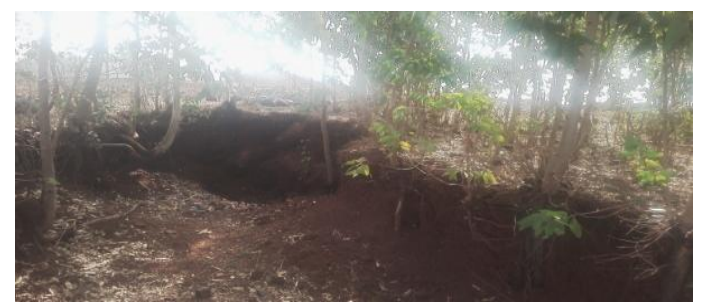

Figure2. stone quarrying impact on loss biodiversity, habitat and deforestation

Source. field survey, 2017

\subsubsection{Land use Change}

According to the table above the majority $37(61.7 \%)$ of the respondents reported that stone quarry changed the land use system including previously cultivated land. According to key informant interview the study area land use/ land cover classes categorized in to three groups that includes, settlments, forest and green areas, and agriculture and grass lands. In the past few decade these land use classes changed to stone quarrying.

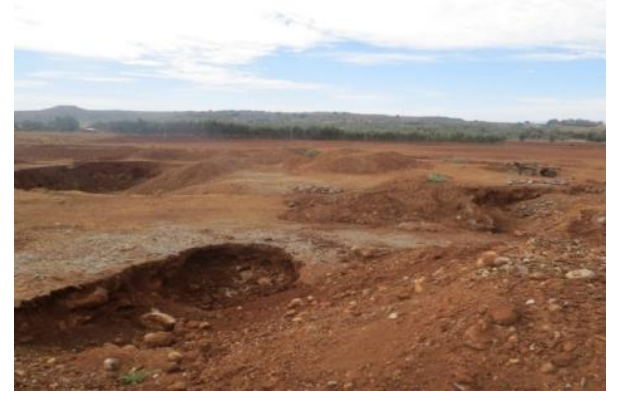

Figure3. the impact of quarrying on land use change from agricultural land use changed to quarrying

Source. field survey, 2017

\subsubsection{Change Landscape}

As it can be showed table 10 , the majority $45(75 \%)$ of the respondents reported that stone quarrying strongly changed landscape resulting from quarry operations in the study area have reached its maximum negative effects. According to the information obtained from local elder key informant interview, destruction to the landscape, lost in vegetation cover, alteration of water courses etc were all observed after the introduction of stone quarrying in the areas. Similarly, field observation also 
observed some of the occurrences of landslides and soil erosion along quarrying site. The soils and stone are vulnerable to swept down the slope during heavy rains. This was as a result of large holes left after stone quarrying. The land is left bare and huge landmasses were wasted hanging dangerous from high land. The high cliffs which were left are mostly moved and others heaped in the quarry. In support of the present study, Mouflis et al. (2008), finding indicated that quarry activity result in the permanent alteration of original land form and the destruction of original vegetation cover.

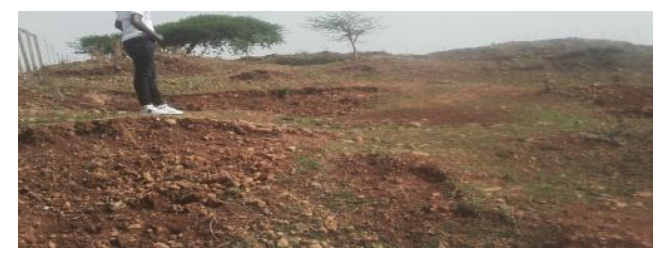

Figure4. The impact of stone quarring on landscape change

\subsubsection{Block free Movement of Animals}

As indicated table above more than half $39(65 \%)$ of the respondents were stated that stone quarrying strongly limits free movement of animals to get their feeding from grazing land. Key informants interview of local elders mentioned that areas that are practicing stone quarrying create hole and slopes, wastes from quarry that are not used like sand, stone, and accumulated soil highly influence the free movement of animals.

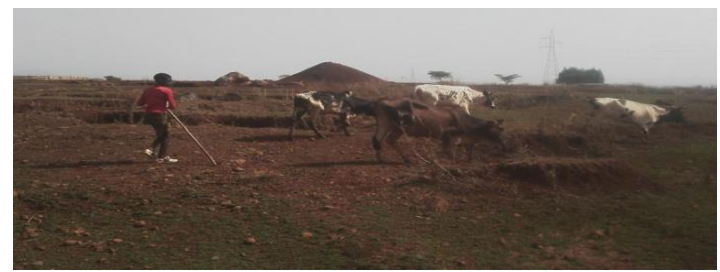

Figure5. stone quarrying impact on movement of animals

Source. field survey, 2017

\subsubsection{Erosion and Sedimentation}

Table above reveal that majority $41(68.3 \%)$ of the respondents were explain that there were high erosion and sedimentation in the area. According to key informant of the kebele agricultural office, stone quarry takes the lion share of the land to become eroded and sediment as the quarry takes place the lands create sloppy and it makes the soil, waste stone, and other materials easy to erode through flood and wind. Those eroded materials are sediment at the lower part of the agricultural lands and water bodies like Streams, Rivers and Lake Tana around Gedro sub- kebele of Zenzelima. Consequently, it is danger for agricultural practice.

\subsubsection{Dereliction of the Quarry Site}

The tables above reveal that the information gathered from questionnaire of the respondents asked about the issue of the state of quarries after operation said that the owners left them as open pits was $66.7 \%$ of the respondents. The information obtain from local elders key informant interview most abandoned quarry sites in zenzelima Kebele area are not put to any use and there is a reluctance to restore or rehabilitate them. The private owners leave the quarry pits open and most of the abandoned ones have been filled with a very small layer of stone rubble and dust where no further rehabilitation takes place. The quarry owners said that filling up of the quarries after use is anexpensive exercise which would not translate to good profits, as the depth of the quarries is large. Also the fact that the land is majorly leased to the quarry owners, and the lessers are after gaining financially from the lease, they do not provide that the land be rehabilitated once the lease period expires. Some respondents said that it can be rehabilitated if the size of open pit is small but it takes much time and soil.

\subsubsection{Loss of Aesthetic Value}

According to the survey questionnaire results in Table 12, 31 (51.6\%) of the respondents revealed that the negative effect of dust pollution was lose of visual scenic. Quarry operation was not only through 
direct removal of habitats but also it accelerated the negative effect by excess emission of dust, water runoff, soil erosion and serious environmental degradation, all these Consequences made the physical environment unattractive scenic value. Regarding to these key informants from local elders and Zenzelima agricultural office expert explained that after the introduction of quarrying activities in the site, there was less physical attractiveness and various rate of gullies, sheet erosion and open pits was observed.

\subsubsection{Death of Livestock}

As it can be understood from Table 13, 40(66.6\%) of the respondents stated that there are no any death in livestock's who were trapped under a blasting/rolling of stone. According interview with agricultural office of the kebele there is no any vibration and blasting and in the study area that disturb and kill of the animals. But some respondents in contrary to the above explained that livestock death is occurring when livestock are in case of searching their feed around the abundant hole.

\subsubsection{Death of Human}

According to the questionnaire more than half $31(51.6 \%)$ of the respondents stone quarrying is the cause for human to be died. The information obtained from local elders key informant interview at sub-kebele of Michaels explained that in 2016 my younger brother was pass away when he was in the operation stone quarrying activities.Another local elder key informant explained that death occur predominantly from falls of ground or rocks, falling from car and hills.

\subsubsection{Property Damage}

The table above show that 35(58.3\%) of the respondents reported that they had not seen any damages on their property because they were not in close proximity to the quarries and most had moved into the area less than a year ago. The rest 25(41.6\%) of respondents reported that their properties had been damaged, majorly by the accumulation of dust inside their houses during transportation and processing. The respondents who responded in this manner were living in close proximity to the quarry sites.

\subsubsection{Air Pollution}

According to the table above half $39(65 \%)$ of the respondents stated that the issue of dust was Source of air pollution in the area. According to local elders key informant interview the issues of air pollution was aggravated because of the fact that the roads in the area were plain earth and are very dusty and because of the constant passage of the heavy trucks, the earth becomes loose and dust particles are always seen suspended in the air especially when there is a lot of wind blowing. When strong winds blow over the quarry sites, a lot of dust is lifted in the air and it causes a lot of nuisance around the area not only that but also durring the transportation of the product huge amount of dust release to the atmosphere.

As we observed in the field survey smoke that released from stone crusher and burded stone the quarry worker used to blust stone easely by addind gasoil(figure 7).

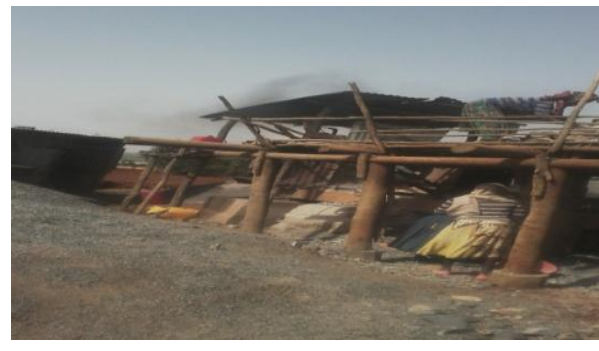

Figure6. impact of quarry on the the air

\section{2. health related effects}

Health can be defined as a state of complete physical, mental and social wellbeing of an individual, and not merely the absence of disease and infirmity (World Health Organization, 2005).

Respondents in the study were asked about health related issues and the major health issues were Physical body damage, coughs and colds, and stress. Each of the mentioned problems was analyzed, and the results were as follows: 
Environment and Social Impacts of Stone Quarrying: South Western Ethiopia, in Case of Bahir Dar Zuria Wereda Zenzelma Kebele

Table2. observation of the impact of stone quarrying on health by respondents

\begin{tabular}{|l|l|l|l|}
\hline Item & Frequency & Percentage (\%) \\
\hline \multirow{2}{*}{$\begin{array}{l}\text { Have you observed the impact of } \\
\text { stone quarrying on human health? }\end{array}$} & Yes & 38 & 63.3 \\
\cline { 2 - 4 } & No & 22 & 36.7 \\
\cline { 2 - 4 } & Total & 60 & 100 \\
\hline
\end{tabular}

Source. field survey, 2017

The above table reveal that the majority $38(63.3 \%)$ of the respondents know about the impact of quarrying on health. Durring local elders key informant interview, an elder said that I observed the impact of stone quarrying on human health physically and mentally through dust, materials of quarry activity.

Table3. health impacts of stone quarrying

\begin{tabular}{|l|l|l|l|}
\hline Health impact & Frequency & Percentage (\%) \\
\hline \multirow{4}{*}{ Stress } & Yes & 32 & 53.3 \\
\cline { 2 - 4 } & No & 28 & 46.7 \\
\cline { 2 - 4 } & total & 60 & 100 \\
\hline \multirow{5}{*}{ Physical body damage } & Yes & 47 & 78.3 \\
\cline { 2 - 4 } & No & 13 & 21.7 \\
\cline { 2 - 4 } & Total & 60 & 100 \\
\hline Coughs and colds & Yes & 34 & 56.7 \\
\cline { 2 - 4 } & No & 26 & 43.3 \\
\cline { 2 - 4 } & Total & 60 & 100 \\
\hline
\end{tabular}

\subsubsection{Stress}

As shown in the table, various impacts of stone quarry on health have been indicated. The respondents having been asked on the issue of stress, more than half $32(53.3 \%)$ of the respondents said that the issue makes them stressed. According to key informant interview from quarry worker Stress related issues occurred due to the kind of tedious work that the workers are subjected to, because of the amount of they earn is dependent on the amount of work done. The levels of noise, vibrations, and dust also contribute highly to the issue of stress. Workers at quarries are exposed to adverse weather conditions such as extremes of temperature, humidity, rain and UV radiation.

\subsubsection{Physical Injury}

According to the results, the highest percentage of the respondents 47(78.3\%) declared that stone quarry have an impact on physical body health. Key informants of the local elders reported that quarry workers exposed at high risk of physical injury, because materials used to operate the activity can hit the body and the nature of quarry have dusts that can damage an eye. In support to this idea we were observed in the field that from the quarryman hand blood blading was occurred because the stone from the upper part fall to the lower part that he was there.

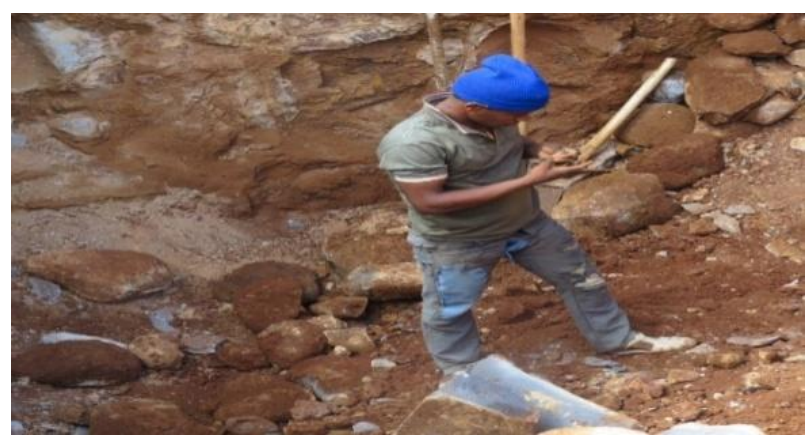

Figure7. physical health damage due to stone quarrying

Source. field survey, 2017

\subsubsection{Coughs and colds}

As shown in the table, various impacts of stone quarry on health have been indicated. More than half of the respondents $34(56.7 \%)$ indicated that there is coughs and colds health problems that occur due 
to quarrying. According to local elder key informant interview the quarry is filled with dust which is left behind during the quarrying process, and there is a lot of dust in the air within those quarries, which accelerates the issue. The workers in the quarries are prone to inhaling the dust throughout the day as they work because they do not have any protective equipment like dust masks to cover themselves as they work. Those loading the stones to the Lorries are most affected as they have to follow the stone cutter machine as it cuts the stones, and blows a lot of dust as it moves on the rails.

\section{CONCLUSION AND RECOMMENDATIONS}

\subsection{Conclusion}

Quarry activity has created several environmental and social problems related to change of landscapes, farming obstacle, Erosion and sedimentation, block free movement of animals, reduction of agricultural yields, contamination of soil, destruction of crops, water pollution, loses of animal life, loss of aesthetic value and loss of biodiversity.

There are also health problems on the workers and local residents related to quarrying activity that associate with inhalation of dust in the air; physical body damage, coughs and colds and stress due to work load of quarrying.

\subsection{Recommendations}

Based on the findings and conclusions of the study, the following recommendations have been suggested to minimize the impacts of stone quarrying on the environment and societies in Zenzelima kebele;

- The government together with the kebele administration to take responsibility of controlling negative impacts.

- Around the quary site shelterbelt should be planted to reduce movement of dust from stone crusher and to sequester the emited carbon dioxide from it.

- Environmental regulations and laws must be enforced by government agencies, local communities and non-governmental organization or pressure groups for protection and preservation of the environment.

- Modern technique should be adopted while quarry undertake to reduce dust pollution and health impact

- Quarry owner must spray water on surfaces of roads in the quarry site to reduce dust emission points.

- Compensation should be given to the local people those who are vulnerable to the impacts such as actual loss of crops, livestock's and house.

- Last but not the least, there is the need for an effective collaboration and coordination among governmental agencies such as the Environmental Protection Agency, the federal mines and energy office, the Agricultural Bureau, the Natural Resource Conservation office and others so that they can perform their roles effectively in dealing with environmental and health problems associated with quarrying activities within the affected community.

\section{REFERENCES}

[1] Anand, P. B. (2006). Waste management in Madras revisited. Environment. Urbanization, 11(20): 161176.

[2] Aronson, J., C., Floret, LeFloc'h, E., Ovalle, C. and R., Pontanier, (1993). Restoration and rehabilitation of degraded ecosystems in arid and semi-arid lands. A view from the South. Restoration Ecology 1:8-17.

[3] Darwish T., Khater C., Jomaa I., Stehouwer R., Shaban A., Hamze M., (2010). Environmental Impact of Quarries on 5668 International Journal of Current Research, Vol. 6, Issue, 03, pp.5664-5669, March, 2014 Natural Resources in Lebanon, Land Degrad. Develop. 22: 345-358 Honourable Supreme.

[4] Mabogunje A.L. (2008). The Challenges of Mobility within Nigeria's Emerging Megacities. In Keynote Address Delivered At The Maiden Annual National Conference On Public Transport, Ikeja, in May pp. 6-8.

[5] Martínez-Ruiz, C., Fernández-Santos, B., Putwain, P.D. and M.J.Fernández-Gomez, (2007).Natural and man-induced revegetation on mining wastes: changes in floristic composition during early succession. Ecological Engineering 30:286-294. 
[6] Mouflis, G. D., Gitas, L. Z., Lliadou, S. and G. H.,Mitri, (2008). Assessment of the visual impact of marble quarry expansion (1984-2000) on the landscape of Thasos Island, NE Greece. Landscape and Urban Planning, 86:92-102.

[7] Nyakeniga, C.A., (2009). An assessment of environmental impacts of stone quarrying activities in Nyambera location, Kisii country. A research project report submitted to Kenyatta university.

[8] Samant J.S., (2014). Environmmental and social impact of stone quarrying: Acase study of Koloapur district. International Journal of Current Research, 6 (3):5664-5669.

[9] Sinha, R.K., Pandey, D.K. and A. K., Sinha. (2000). Mining and the environment: a case study from Bijolia quarrying site in Rajasthan. The Environmentalist 20: 195-203.

[10] Tanko,A., (2007). "Environmental concerns, assessment and protection procedures for Nigeria's oil industry"Centre for Development studies and the school of Geography, Geol. Environ.Sci.,BUK, Nigeria, pp.1.

[11] Wang.A., (2007). Principle of Environmental Impact Assessment Best Practice." International Association for Impact Assessment. "Environ. Prot. China: The role of law" pp. 120-128

[12] WorldRainforest Movement (2004). http://wrm.org.uy/oldsite/deforestation/mining/book.html/Accssed on February 20, 2016.

[13] Zenzelma Kebele Agricultural Office (ZKAO), 2017

Citation: Awoke Endalew, et.al, " Environment and Social Impacts of Stone Quarrying: South Western Ethiopia, in Case of Bahir Dar Zuria Wereda Zenzelma Kebele", International Journal of Research in Environmental Science (IJRES), vol.5,no. 2, pp. 29-38, 2019. Available: DOI: http://dx.doi.org/10.20431/24549444.0502005

Copyright: (C) 2019 Authors. This is an open-access article distributed under the terms of the Creative Commons Attribution License, which permits unrestricted use, distribution, and reproduction in any medium, provided the original author and source are credited. 